\title{
Unconventional Treatment Options in Severe Asthma: An Overview
}

\author{
Hoan Linh Banh
}

Faculty of Pharmacy and Pharmaceutical Sciences, University of Alberta, Edmonton, Alberta, Canada

Received, July 29, 2011; Accepted, October 7, 2011; Published, October 7, 2011.

\begin{abstract}
In Canada, asthma is the leading cause of admission in hospital. About of $80 \%$ of the death from asthma is preventable. Severe asthma is defined as a patient with persistent symptoms despite the use of adequate controller therapy, including multiple courses of oral glucocorticosteroids. However, about $10 \%$ of patients with severe asthma remain poorly controlled despite optimal treatment and these patients have the greatest morbidity and mortality. The management of refractory severe asthma remains extremely challenging. For patients with refractory severe asthma, the adjunct therapies recommended by national guidelines only included oral glucocorticosteroid and anti-IgE antibody (omalizumab) therapy. Currently, there is limited published literature on the unconventional treatments such as methotrexate, cyclosporine, gold and antimicrobials treatments, for refractory severe asthma. The objective of this review article is to provide an updated therapeutic overview of unconventional treatment options for refractory severe asthma.
\end{abstract}

This article is open to POST-PUBLICATION REVIEW. Registered readers (see "For Readers") may comment by clicking on ABSTRACT on the issue's contents page.

\section{INTRODUCTION}

Asthma is defined as a chronic inflammatory disorder of the airways and is associated with airway hyperresponsiveness that leads to recurrent episodes of wheezing, breathlessness, chest tightness, and coughing $(1,2)$. In Canada, asthma is the leading cause of admission in hospital(3). About of $80 \%$ of the death from asthma is preventable $(4,5)$. Inhaled corticosteroids are the cornerstone treatment of asthma $(2,6)$.

Severe asthma is a complex syndrome with different clinical phenotypes(7-9). Severe asthma is defined as a patient with persistent symptoms despite the use of adequate controller therapy, including multiple courses of oral glucocorticosteroids(10). The WHO uniform definition for severe asthma is "uncontrolled asthma which can result in risk of frequent severe exacerbations (or death) and /or adverse reactions to medications and/or chronic morbidity (including impaired lung function or reduced lung growth in children"(11). Patients with severe asthma are divided into three groups: 1) untreated severe asthma, 2) difficult to treat severe asthma, 3) treatment resistant severe asthma. The last group of patients includes patients with asthma which control is not achieved despite the highest level of recommended treatment: refractory asthma and corticosteroid-resistant asthma, and asthma for which control can be maintained only with the highest level of recommended treatment. The management of severe asthma must include:(11)

1. Accurate diagnosis with pulmonary expiratory flow rate or spirometry

2. Accurate assessment of severity

3. Assessment and prevention of risk factors

4. Assessment and control of comorbidities

5. Appropriate therapy including ICS, short-acting $\beta_{2}$-agonists and long acting $\beta_{2}$-agonists

6. Appropriate drug delivery devices

7. Assessment of control

8. Ongoing support in self-management and patient education

9. Well trained health professionals

The goal of asthma management is to achieve and maintain clinical control. Medications used to treat asthma are categorized in 2 groups: controllers and relievers. Controllers are medications which are taken on a scheduled daily basis for long-term; they include inhaled and systemic glucocorticosteroids,

Corresponding Author: Dr. H.L. Banh, Faculty of Pharmacy and Pharmaceutical Sciences, University of Alberta, Edmonton, $\mathrm{AB}$, Canada. 
leukotriene modifiers, long-acting $\beta_{2}$-agonists in combination with inhaled glucocorticosteroids, sustained release theophylline, cromones and antiIgE (2). Relievers are medications used on an as needed basis. They include rapid acting inhaled $\beta_{2^{-}}$ agonists, inhaled atni-cholinergics, short-acting theophylline and short-acting oral $\beta_{2}$-agonists (2). Inhaled glucocorticosteroids are currently are currently the most effective anti-inflammatory medications for the treatment of severe asthma. This have shown to reduce asthma symptoms, improved quality of life, improve lung function, decrease airway hyperresponsiveness, controlling airway inflammation, reduce frequency and severity of exacerbations (2). Many patients with severe asthma respond to a combination of high dose inhaled corticosteroids (fluticasone $\geq 1 \mathrm{mg}$ /day or equivalent) and $\beta_{2}$-adrenergic receptor agonists (1214). However, about $10 \%$ of patients with severe asthma remain poorly controlled despite optimal treatment and these patients have the greatest morbidity and mortality $(9,15,16)$. The management of refractory severe asthma remains extremely challenging (17-19). These patients have poor quality of life and require multiple emergency room visits, hospitalizations and unscheduled physician visits $(15,20)$. For patients with refractory severe asthma, the adjunct therapies recommended by national guidelines only included oral glucocorticosteroid and anti-IgE antibody (omalizumab) therapy $(2,6)$. Currently, there is limited published literature on the unconventional treatments of refractory severe asthma $(8,21-23)$. The objective of this review article is to provide an updated therapeutic overview of unconventional treatment options for refractory severe asthma.

\section{CURRENT UNCONVENTIONAL TREATMENT OPTIONS}

\section{Anti-infectives}

\section{Antibiotics}

Macrolide antibiotics such as clarithromycin and azithromycin both inhibit bacterial protein synthesis by binding $50 \mathrm{~S}$ submit of the $70 \mathrm{~S}$ bacterial ribosome and exhibit anti-inflammatory effects (2427). The macrolides have been shown to reduce IL8 and neutrophils, major inflammatory mediator, in non-eosinophil asthma $(28,29)$. It has been suggested that there is an association between atypical bacterial infection such as Chlamydia pneumoniae and mycoplasma pneumoniae, and asthma (26, 30-33). Results from studies in both adults and pediatric patients showed that the presence of atypical infection is associated with increased inflammatory response to the airways (31, 34).

Studies on the use of macrolides in the treatment of systemic steroid-dependent asthma demonstrated that there was no significant difference between placebo and macrolide treatment with respect to $\mathrm{FEV}_{1}$ improvement and or reduction in systemic glucocorticoid dose between the two groups (35). However, recent studies showed that the addition of a macrolide improved quality of life, increase $\mathrm{FEV}_{1}$ from baseline, reduction in nocturnal symptoms, and reduction of neutrophil count (36-40).

Current clinical guidelines do not recommend the use of macrolides as routine treatment of refractory severe asthma. Nevertheless, there is increasing evidence to show that macrolides have a role in the management of severe asthma and asthma exacerbation $(38,39)$. There are, however, risks associated with the use of macrolides, mainly, the development of antibiotic resistance. Therefore, before initiating a macrolide in patients with severe asthma the discussion of risks versus benefits with patients is essential.

\section{Anti-fungal}

Allergic bronchopulmonary aspergillosis (ABPA) caused by hypersensitivity to Aspergillus fumigates manifest in patients with severe asthma (41). These patients also have a positive skin test to Aspergillus fumigates with increased serum $\operatorname{IgE}$ and $\operatorname{IgG}$ to Aspergillus fumigates (42). The standard treatment of inflammation for ABPA is the use of glucocorticosteroids. Recently, studies showed a reduction of inflammation, oral corticosteroid dose, total $\mathrm{IgE}$, asthma exacerbation and an improvement of $\mathrm{FEV}_{1}$ with the treatment of the azoles such as ketoconazole and itraconazole (43-45). Current recommendation is to consider itraconazole in patients who are not responding to oral corticosteroid or required a corticosteroid sparing drug (46).

Severe asthma fungal sensitization (SAFS) is a distinct asthma phenotype in severe asthma patients. Patients with SAFS have severe asthma and positive testing for fungal (Alternaria alernata or cladosporium herbarum) sensitization but 
exclude ABPA. The sensitivity to molds is associated with asthma severity, hospitalization, and pulmonary hypersensitivity $(32,47-49)$. In addition, these molds are capable of germination, infection and colonization in the respiratory tract of patients with asthma (50). Clinical trials showed that the treatment with fluconazole resulted in significant improvement in lung function, quality of life, symptom scores and reduction in steroid requirement $(51,52)$. However, all of the monitoring parameters returned to baseline after the discontinuation of therapy (51). In general, fluconazole was well tolerated; however, the therapy is quite costly. It is recommended that the treatment of fluconazole should be patient specific.

\section{Immunomodulating Agents}

\section{Methotrexate}

Neutrophils are polymorphonuclear leukocytes and they play an important part in the immune system (53). They are the first line of defence against bacterial and fungal infections. Also, they play a major role in the inflammatory process by releasing inflammatory mediators which has a significant effect on patients with asthma (54).

Methotrexate is a folic acid antagonist with antineoplastic, immunosuppressive and antiinflammatory effects; it is one of the most studied agents in asthma. The exact mechanism of methotrexate in asthma is unknown. It has been proposed that methotrexate may inhibit neutrophils (55-58). Some evidence suggested that methotrexate may enhance the sensitivity of monocytes to glucocortoids in severe asthma patients (59). The common doses used in the studies were $7.5-30 \mathrm{mg}$ weekly. The duration ranges from $3-6$ months.

Clinical trials evaluating the comparison of methotrexate with placebo demonstrated a modest steroid-sparing effect with methotrexate (60). The treatment of methotrexate was associated with significant hepatic and gastrointestinal side effects without much improvement in lung function or airway hyperresponsiveness.

A recent double-blind, randomized, placebocontrol study of 46 severe asthma patient treated with methotrexate $10 \mathrm{mg} /$ week for 12 months. The results showed a significant reduction $(>50 \%)$ in steroid dose in the methotrexate group (61).
Common side effects were hepatic, gastrointestinal and oral ulcer but were transient and reversible.

It has been suggested that methotrexate should be given first consideration in patients whose symptoms are not controlled with long term oral glucocorticosteroid (21). However, the decision to initiate methotrexate must be based on risk versus benefit assessment for the patients.

\section{Cyclosporine}

Evidence supported the association with asthma symptoms and increased of eosinophils and $\mathrm{T}$ lymphocytes (62). Studies showed an increased of $\mathrm{CD} 25+, \mathrm{CD} 4+\mathrm{T}$ lymphocytes in the peripheral blood of asthma patients who were unresponsive to oral corticosteroid as compared with asthma patients who were responsive to oral corticorsteroid (63-65).

Cyclosporine, a fungal metabolite, inhibits CD4+ T-cell activation (66-68). Randomized, placebo controlled trials showed a small reduction in daily oral corticorsteroid dose and slight improvement in lung function $(66,69-71)$. The duration of treatment in the studies was short with longest treatment period of 36 weeks (70). The studies did not examine the mechanism of action for cyclosporine by monitoring the inflammatory mediators. The most common side effects seen were elevation of diastolic blood pressure and serum creatinine that are reversible at the discontinuation of cyclosporine. Based on the current evidence and the safety profile, it is recommended that cyclosporine should not be routinely initiated in severe asthma patients, and should only be prescribed and monitored by trained specialist.

\section{Gold}

Gold sodium thiomalate, gold thioglucose, and auranofin are commonly used in gold therapy. It is an immunomodulator; the exact mechanism of action is unknown. It has been shown to reduce neutrophils and macrophage phagocytosis and lymphocyte reactivity (72) Clinical trials did not show clinical significant improvement in symptoms, pulmonary function tests, or reduction in oral steroid dose (73-76). The common dosing regimen used in the studies was $25-50 \mathrm{mg}$ a week orally or intramuscularly. The common reported reversible side effects were gastrointestinal upset, diarrhea, pruritic rash, oral ulceration, proteinuria 
and nephrotic syndrome. Given the lack of efficacy and associated toxicities, routine treatment with gold in severe asthma patients is not recommended. It should only be prescribed by experienced specialists.

\section{Intravenous immune globulin (IVIG)}

IVIG consists of pooled human plasma IgG antibodies. Studies demonstrated that the use of IVIG is effective in glucocorticoid dependent asthma patients (77-80). The exact mechanism of glucocorticosteroid sparing effects is unclear. It has been shown to suppress lymphocyte activation and cytokine dependent lymphocyte proliferation (79, 81, 82). IVIG improves glucocorticoid receptor sensitivity in patients who are glucocorticoid resistant (83).

Treatment with IVIG resulted in a reduction of asthma symptoms, oral steroid dose by as much as threefold and total serum $\operatorname{IgE}(78-80,84)$. As an adjunctive therapy, IVIG, reduces glucocorticoid requirement, and hospitalization; but it does not improve lung function in patient with severe steroid dependent asthma (85).

In general, IVIG is well tolerated; common reported self-limiting side effects include headache and nausea. IVIG comes from pooled human plasma, although there is no risk of transmission of viral hepatitis, however, there is still a slight possibility of IVIG transmission of undefined viral infection. In rare cases, IVIG has been associated with interstitial nephritis and aseptic meningitis (86). Because IVIG contains a trace of IgA, IVIG should be avoided in patients with IgA deficiency as it could lead to anaphylactic reaction (87-90).

\section{Azathioprine}

Azathioprine is an immunosuppressive agent that reversibly reduces monocyte numbers in circulation and tissues (91), impairs synthesis of gamma globulin (IgM, IgG) (92), long term immunosuppression decreases the number of cutaneous Langerhans cells (93) impairs responses of helper $\mathrm{T}$ cell dependent B cells (94), impairs function of $\mathrm{T}$ suppressor cells (94) and impairs $\mathrm{T}$ cell lymphocyte function and IL-2 production (95). Because azathioprine has been shown to be effective in other inflammatory conditions, it is reasonable to expect that it would also be effective in patients with asthma. Nevertheless, there are limited studies to address the effectiveness of azathioprine in patients with asthma. Azathioprine did not improve $\mathrm{FEV}_{1}$ or reduce asthma exacerbations (96). Due to insufficient evidence, it is recommended that more clinical trials are required to investigate the effectiveness of azathioprine in asthma patients.

\section{Colchicine}

Colchicine is an inexpensive anti-inflammatory, immunomodulating agent with very few adverse effects, has been in use for over 3000 years (97, 98). It is commonly used for treatment of gout. Colchicine exerts its anti-inflammatory action by interfering with leukocyte chemotaxis and lysosomal enzyme release, (99-101) and inhibiting histamine release from basophils $(102,103)$. The use of colchicine as an adjunct to oral or inhaled corticosteroid has been studied in patients with asthma. Results from studies failed to show improvement in clinical outcomes or reduction in corticosteroid dose in patients with mild to moderate asthma (104-108). Data from these studies failed to support the use of colchicine as an adjunct therapy in patients with glucocorticoid dependent asthma.

\section{Dapsone}

Dapsone is a sulfone antibiotic commonly used to treat leprosy. It interferes with the myeloperoxidase-hydrogen peroxide-halide mediated cytotoxic system in neutrophils resulting in inhibition of antibody adherence to neutrophils $(109,110)$. Currently, there is only one open label study of dapsone in 10 patients with asthma (111). The study showed that reduction of oral corticosteroid was possible in seven patients however all ten patients experienced dose-related hemolysis necessitated the discontinuation from the study. Due to the side effects and lack of efficacy evidence, dapsone is not recommended as an adjunct therapy.

\section{Hydroxychloroquine}

Hydroxychloroquine is used in malarial infection, rheumatoid arthritis and systemic lupus erythematosus. The proposed mechanism for hydroxychloroquine is that it inhibits phospholipase $\mathrm{A} 2$, and phagocytosis and decreases stimulation of 
CD4+ lymphocytes (112). The possible antiinflammatory properties are a result of decrease leukotriene and prostaglandin synthesis (113). Open label studies shown hydroxychloroquine had corticosteroid-sparing effects, improved $\mathrm{FEV}_{1}$ and FVC and reduced IgE levels. $(114,115)$ Yet, in a double-blind placebo-controlled trial with nine patients, hydroxychloroquine failed to show oral corticosteroid-sparing effects and pulmonary function improvements (116). Overall, hydroxychloroquine was well tolerated. Although rare, it can cause irreversible retinal damage. Given that there is insufficient efficacy and safety data, hydroxychloroquine is not recommended as an adjunct in the treatment of asthma.

\section{BIOLOGICS}

\section{Omalizumab}

Basophil, mast cell and particularly eosinophil degranulation play a central role in allergic asthma which occurs in presence of high IgE level (117119). Increased numbers of eosinophils are associated with the severity of asthma (120-122). Omalizumab (Xolair ${ }^{\mathbb{B}}$, Genetech/Novartis) is a recombinant humanized monoclonal anti-IgE antibody that binds to the Fc-region of the $\operatorname{IgE}$ molecule, and so prevents IgE from interacting with high or low-affinity $\mathrm{IgE}$ receptors (FceR1 and FceR11) and resulting in a reduction of circulating free $\operatorname{IgE}(119$, 123-125). Omalizumab also downregulates FceR1 receptors in circulating basophils, in mast cells, and in circulating antigen presenting cells. This is believed to result in a downgrade of inflammatory responses mediated by helper $\mathrm{T}$ cells $(125,126)$. Omalizumab received approval by the US Food and Drug Administration (2003) and Health Canada (2005) for use in patients who are 12 years or older with moderate to severe persistent asthma, who are not controlled with inhaled corticosteroids, have an serum IgE 30-700 International Units (IU) $\cdot \mathrm{mL}^{-1}$, and also test positive for reactivity to a perennial airborne allergen. Currently, omalizumab is the only biologic approved for the treatment of asthma. Numerous clinical trials of patients with mild to severe allergic asthma showed omalizumab significantly reduced serum IgE, inhaled corticosteroid dose requirement and number of asthma exacerbations and improved quality of life compared to placebo (127). However, the author noted significant placebo effect in the control group and questioned the true effects of omalizumab. Recent studies on adolescents and adults also showed similar results (128-130). Nevertheless, omalizumab has not shown to consistently improve lung functions. In general, omalizumab is well tolerated, but studies lack longterm safety data. According to the recent recommendations, omalizumab is an option in patients with severe allergic asthma with elevated serum $\operatorname{IgE}$ or demonstrated allergic sensitization (2).

\section{Anti-tumor Necrosis Factor $\alpha$}

Tumor necrosis factor $\alpha$ are inflammatory cytokines released by mast cells,(131) and are elevated in patients with severe asthma (131-135). Patients who were given exogenous tumor necrosis factor $\alpha$ developed airway hyperresponsiveness and airway neutrophilia $(136,137)$. The exact mechanism of airway inflammation is unclear. It is believed that tumor necrosis factor $\alpha$ affects the airway smooth muscles by the release of cysteinyl leukotrienes $\mathrm{C}_{4}$ and $\mathrm{D}_{4}$, recruits both neutrophils and eosinophils, activation of T cells $(138,139)$ and enhancement of cytotoxic activities of the leukocytes $(140,141)$. Anti- tumor necrosis factor $\alpha$ monoclonal antibodies such as infliximab, and etanercept, have been studied in patients with refractory severe asthma evaluating $\mathrm{FEV}_{1}, \mathrm{FVC}$, quality of life, and number of exacerbations produced conflicting findings (134, 135, 142-144). A recent phase II randomized placebo-controlled trial with golimumab, a monoclonal antibody, in patients with severe persistent asthma failed to show benefits over placebo and was prematurely terminated at 24 weeks (145). Of concern, patients in the treatment group had increased serious side effects such as infections, and eight malignancies such as breast cancer, B cell lymphoma, melanoma, cervical carcinoma, renal cell carcinoma, colon cancer and basal cell carcinomas while none was reported in the placebo group. Similar infections and malignancies were reported in a recent study on the administration of infliximab for six months in patients with chronic obstructive pulmonary disease (146). In addition, there have been numerous reporting of malignancies in patients with rheumatoid arthritis treated with anti- tumor necrosis factor $\alpha$ (147-149). Although atni- tumor necrosis factor $\alpha$ remains a viable option in the treatment of refractory severe asthma, careful 
evaluation of risks versus benefits must be taken in consideration before initiating these biologics.

\section{OTHERS}

\section{Heparin}

Heparin is a glycosaminoglycan commonly used for its anticoagulation effects. Heparin and heparin-like compounds are ubiquitous in the lung, intestine and liver (150). It is found in cytoplasm of mast cells as granules and it is released under inflammatory conditions such as asthma. It is hypothesized that heparin inhibits inositol triphosphate receptors which prevents mast cell degranulation, and histamine release (151-159). In patients with atopic asthma, plasma level of heparin, and heparin-like compounds are elevated resulting in altered platelet function. Early studies with high dose intravenous heparin in patients with asthma revealed subjective improvement of asthma symptoms but no objective improvement $(160,161)$. The results were confirmed with inhaled heparin (162). In subsequent studies, inhaled heparin inhibits bronchoconstriction in patients with exerciseinduced asthma $(163,164)$. The effect is also seen with inhaled low molecular weight heparin, enoxaparin (165). Trials of inhaled heparin on bronchoconstriction effects caused by bronchostimulants such as methacholine, yield mixed results (166-168). Case reports of patients with corticosteroid resistant asthma responded to inhaled heparin during exacerbations (169).

No bleed complications or significant changes in partial thrombin time, or anti-Xa activities were reported in any of the studies. Nonetheless, the use of heparin for the anti-inflammatory properties is hindered by the fear of bleeding. The requirement of high dose of heparin to achieve antiinflammatory effects limits its use in severe asthma patients. Currently, efforts are being devoted to develop chemically modified heparin without the anticoagulation effects (170). Thus far, all the studies are limited to small sample size. Larger prospective placebo-controlled studies are needed to determine efficacy and toxicity of heparin in patients with asthma.

\section{Furosemide}

Furosemide, a loop diuretic, inhibits the sodium/potassium/chloride co-transporter in the ascending loop of Henle which produces potent dieresis (171). The exact mechanism of furosemide in asthma is not known. It is not a bronchodilator as it does not inhbit acetylcholine, histamine or tachykinin induced bronchoconstriction $(172,173)$. It is proposed that furosemide reduce chloride channel activity which inhibits the release of inflammatory mediators such as histamine and leukotrienes by eosinophils (174).

Two small studies using inhaled furosemide in combination with lysine acetylsalicylate (LASA) demonstrated significant reduction in glucocorticosteroid requirement in patients with chronic asthma $(175,176)$. Studies evaluated the use of inhaled furosemide in acute asthma exacerbation yielded mixed results (177-180). A follow up case series showed clinical improvement in patients with severe asthma exacerbations who were unresponsive to conventional therapies (180). The current efficacy and toxicity data are lacking. Large double blinded placebo controlled trials are needed to establish the role of loop diuretics in the treatment of asthma.

\section{CONCLUSION}

There is significant co-morbidities exist in patients who are refractory to standard treatment.(181) The management of refractory severe asthma requires a systematic approach consists of correct diagnosis, identification of co-morbidities, patient specific treatment and assessment of adherence. Asthma severity is intertwined with the level of control, therapy prescribed and responsiveness to prescribed therapy (11). When considering the use of unconventional therapies for asthma, only trained and experienced pulmonologists should initiate these therapies. The weigh risks versus benefits and cost must be taken into account when making the decision.

\section{REFERENCES}

1. World health organization. chronic respiratory disease - asthma. http://www.who.int.login.ezproxy.library.ualberta.c a/respiratory/asthma/definition/en/. Accessed September 18, 2010.

2. Global strategy for asthma management and prevention. Global initiative for asthma (GINA); 2008.

3. Asthma society of canada. asthma facts and statistics. 
http://www.asthma.ca/corp/newsroom/pdf/asthmast ats.pdf_Accessed September 23, 2010.

4. Statistics canada. table 102-0551 - deaths and mortality rate, by selected grouped causes, age group and sex, canada, annual (table), CANSIM (database). Accessed September 28, 2010.

5. Asthma society of canada. asthma facts and statistics.

http://www.asthma.ca/corp/newsroom/pdf/asthmast ats.pdf_Accessed September 23, 2010.

6. National asthma education and prevention program: Expert panel report III: Guidelines for the diagnosis and management of asthma. [internet]. bethesda., MD: National heart, lung and blood institute, 2007 [Accessed april 2011]. available from [Internet]. Available

from: http://www.nhlbi.nih.gov/guidelines/asthma/asthgdl n.pdf.

7. Bush A, Menzies-Gow A. Phenotypic differences between pediatric and adult asthma. Proc Am Thorac Soc. 2009 Dec;6(8):712-9.

8. Holgate ST, Polosa R. The mechanisms, diagnosis, and management of severe asthma in adults. Lancet. 2006 Aug 26;368(9537):780-93.

9. Moore WC, Peters SP. Severe asthma: An overview. J Allergy Clin Immunol. 2006 Mar;117(3):487,94; quiz 495.

10. Proceedings of the ATS workshop on refractory asthma: Current understanding, recommendations, and unanswered questions. american thoracic society. Am J Respir Crit Care Med. 2000 Dec;162(6):2341-51.

11. Bousquet J, Mantzouranis E, Cruz AA, Ait-Khaled $\mathrm{N}$, Baena-Cagnani CE, Bleecker ER, et al. Uniform definition of asthma severity, control, and exacerbations: Document presented for the world health organization consultation on severe asthma. J Allergy Clin Immunol. 2010 Nov;126(5):926-38.

12. Pauwels RA, Lofdahl CG, Postma DS, Tattersfield AE, O'Byrne P, Barnes PJ, et al. Effect of inhaled formoterol and budesonide on exacerbations of asthma. formoterol and corticosteroids establishing therapy (FACET) international study group. N Engl J Med. 1997 Nov 13;337(20):1405-11.

13. Woolcock A, Lundback B, Ringdal N, Jacques LA. Comparison of addition of salmeterol to inhaled steroids with doubling of the dose of inhaled steroids. Am J Respir Crit Care Med. 1996 May;153(5):1481-8.

14. Gibson PG, Powell H, Ducharme FM. Differential effects of maintenance long-acting beta-agonist and inhaled corticosteroid on asthma control and asthma exacerbations. J Allergy Clin Immunol. 2007 Feb;119(2):344-50.

15. Moore WC, Bleecker ER, Curran-Everett D, Erzurum SC, Ameredes BT, Bacharier L, et al. Characterization of the severe asthma phenotype by the national heart, lung, and blood institute's severe asthma research program. J Allergy Clin Immunol. $2007 \mathrm{Feb} ; 119(2): 405-13$.

16. Ogawa Y, Calhoun WJ. Phenotypic characterization of severe asthma. Curr Opin Pulm Med. 2010 Jan;16(1):48-54.

17. Morjaria JB, Polosa R. Recommendation for optimal management of severe refractory asthma. J Asthma Allergy. 2010 Jul 26;3:43-56.

18. Currie GP, Douglas JG, Heaney LG. Difficult to treat asthma in adults. BMJ. 2009 Feb 24;338:b494.

19. Moore WC, Meyers DA, Wenzel SE, Teague WG, $\mathrm{Li} \mathrm{H}, \mathrm{Li} \mathrm{X}$, et al. Identification of asthma phenotypes using cluster analysis in the severe asthma research program. Am J Respir Crit Care Med. 2010 Feb 15;181(4):315-23.

20. Antonicelli L, Bucca C, Neri M, De Benedetto F, Sabbatani P, Bonifazi F, et al. Asthma severity and medical resource utilisation. Eur Respir J. 2004 May;23(5):723-9.

21. Polosa R. An overview of chronic severe asthma. Intern Med J. 2008 Mar;38(3):190-8.

22. Polosa R, Benfatto GT. Managing patients with chronic severe asthma: Rise to the challenge. Eur J Intern Med. 2009 Mar;20(2):114-24.

23. Polosa R, Morjaria J. Immunomodulatory and biologic therapies for severe refractory asthma. Respir Med. 2008 Nov;102(11):1499-510.

24. Mazzei T, Mini E, Novelli A, Periti P. Chemistry and mode of action of macrolides. J Antimicrob Chemother. 1993 Mar;31 Suppl C:1-9.

25. Oishi K, Sonoda F, Kobayashi S, Iwagaki A, Nagatake $T$, Matsushima $K$, et al. Role of interleukin-8 (IL-8) and an inhibitory effect of erythromycin on IL-8 release in the airways of patients with chronic airway diseases. Infect Immun. 1994 Oct;62(10):4145-52.

26. Sakito O, Kadota J, Kohno S, Abe K, Shirai R, Hara K. Interleukin 1 beta, tumor necrosis factor alpha, and interleukin 8 in bronchoalveolar lavage fluid of patients with diffuse panbronchiolitis: A potential mechanism of macrolide therapy. Respiration. 1996;63(1):42-8.

27. Piacentini GL, Peroni DG, Bodini A, Pigozzi R, Costella S, Loiacono A, et al. Azithromycin reduces bronchial hyperresponsiveness and neutrophilic airway inflammation in asthmatic children: A preliminary report. Allergy Asthma Proc. 2007 Mar-Apr;28(2):194-8.

28. Gibson PG, Simpson JL, Saltos N. Heterogeneity of airway inflammation in persistent asthma : Evidence of neutrophilic inflammation and increased sputum interleukin-8. Chest. 2001 May;119(5):1329-36.

29. Berry M, Morgan A, Shaw DE, Parker D, Green R, Brightling $\mathrm{C}$, et al. Pathological features and inhaled corticosteroid response of eosinophilic and 
non-eosinophilic asthma. Thorax. 2007 Dec;62(12):1043-9.

30. Cunningham AF, Johnston SL, Julious SA, Lampe FC, Ward ME. Chronic chlamydia pneumoniae infection and asthma exacerbations in children. Eur Respir J. 1998 Feb;11(2):345-9.

31. Wark PA, Johnston SL, Simpson JL, Hensley MJ, Gibson PG. Chlamydia pneumoniae immunoglobulin $\mathrm{A}$ reactivation and airway inflammation in acute asthma. Eur Respir J. 2002 Oct;20(4):834-40.

32. Martin RJ, Kraft M, Chu HW, Berns EA, Cassell GH. A link between chronic asthma and chronic infection. J Allergy Clin Immunol. 2001 Apr;107(4):595-601.

33. Biscione GL, Corne J, Chauhan AJ, Johnston SL. Increased frequency of detection of chlamydophila pneumoniae in asthma. Eur Respir J. 2004 Nov;24(5):745-9.

34. Chauhan AJ, Inskip HM, Linaker $\mathrm{CH}$, Smith $\mathrm{S}$, Schreiber J, Johnston SL, et al. Personal exposure to nitrogen dioxide (NO2) and the severity of virusinduced asthma in children. Lancet. 2003 Jun 7;361(9373):1939-44.

35. Richeldi L, Ferrara G, Fabbri LM, Lasserson TJ, Gibson PG. Macrolides for chronic asthma. Cochrane Database Syst Rev. 2005 Oct 19;(4)(4):CD002997.

36. Hahn DL, Plane MB, Mahdi OS, Byrne GI. Secondary outcomes of a pilot randomized trial of azithromycin treatment for asthma. PLoS Clin Trials. 2006 Jun;1(2):e11.

37. Gotfried MH. Macrolides for the treatment of chronic sinusitis, asthma, and COPD. Chest. 2004 Feb;125(2 Suppl):52S,60S; quiz 60S-61S.

38. Johnston SL, Blasi F, Black PN, Martin RJ, Farrell DJ, Nieman RB, et al. The effect of telithromycin in acute exacerbations of asthma. N Engl J Med. 2006 Apr 13;354(15):1589-600.

39. Simpson JL, Powell H, Boyle MJ, Scott RJ, Gibson PG. Clarithromycin targets neutrophilic airway inflammation in refractory asthma. Am J Respir Crit Care Med. 2008 Jan 15;177(2):148-55.

40. Kraft M, Cassell GH, Pak J, Martin RJ. Mycoplasma pneumoniae and chlamydia pneumoniae in asthma: Effect of clarithromycin. Chest. 2002 Jun;121(6):1782-8.

41. Greenberger PA. Clinical aspects of allergic bronchopulmonary aspergillosis. Front Biosci. 2003 Jan 1;8:s119-27.

42. Agarwal R. Allergic bronchopulmonary aspergillosis. Chest. 2009 Mar;135(3):805-26.

43. Wark PA, Gibson PG, Wilson AJ. Azoles for allergic bronchopulmonary aspergillosis associated with asthma. Cochrane Database Syst Rev. 2004;(3)(3):CD001108.
44. Stevens DA, Schwartz HJ, Lee JY, Moskovitz BL, Jerome DC, Catanzaro A, et al. A randomized trial of itraconazole in allergic bronchopulmonary aspergillosis. N Engl J Med. 2000 Mar 16;342(11):756-62.

45. Wark PA, Hensley MJ, Saltos N, Boyle MJ, Toneguzzi RC, Epid GD, et al. Anti-inflammatory effect of itraconazole in stable allergic bronchopulmonary aspergillosis: A randomized controlled trial. J Allergy Clin Immunol. 2003 May;111(5):952-7.

46. Patterson K, Strek ME. Allergic bronchopulmonary aspergillosis. Proc Am Thorac Soc. 2010 May;7(3):237-44.

47. Agarwal R, Gupta D. Severe asthma and fungi: Current evidence. Med Mycol. 2011 Apr;49 Suppl 1:S150-7.

48. Matsuoka H, Niimi A, Matsumoto $H$, Ueda $T$, Takemura M, Yamaguchi M, et al. Specific IgE response to trichophyton and asthma severity. Chest. 2009 Apr;135(4):898-903.

49. Niedoszytko M, Chelminska M, Jassem E, Czestochowska E. Association between sensitization to aureobasidium pullulans (pullularia sp) and severity of asthma. Ann Allergy Asthma Immunol. 2007 Feb;98(2):153-6.

50. Denning DW, O'Driscoll BR, Hogaboam CM, Bowyer P, Niven RM. The link between fungi and severe asthma: A summary of the evidence. Eur Respir J. 2006 Mar;27(3):615-26.

51. Denning DW, O'Driscoll BR, Powell G, Chew F, Atherton GT, Vyas A, et al. Randomized controlled trial of oral antifungal treatment for severe asthma with fungal sensitization: The fungal asthma sensitization trial (FAST) study. Am J Respir Crit Care Med. 2009 Jan 1;179(1):11-8.

52. Ward GW,Jr, Woodfolk JA, Hayden ML, Jackson S, Platts-Mills TA. Treatment of late-onset asthma with fluconazole. J Allergy Clin Immunol. 1999 Sep;104(3 Pt 1):541-6.

53. Douwes J, Gibson P, Pekkanen J, Pearce N. Noneosinophilic asthma: Importance and possible mechanisms. Thorax. 2002 Jul;57(7):643-8.

54. Barnes PJ, Chung KF, Page CP. Inflammatory mediators of asthma: An update. Pharmacol Rev. 1998 Dec;50(4):515-96.

55. Tsai JJ, Wang TF, Wang SR. The inhibitory effect of methotrexate on PAF-induced neutrophil and eosinophil locomotion in asthmatic patients. Asian Pac J Allergy Immunol. 1994 Jun;12(1):65-71.

56. Suarez CR, Pickett WC, Bell DH, McClintock DK, Oronsky AL, Kerwar SS. Effect of low dose methotrexate on neutrophil chemotaxis induced by leukotriene B4 and complement C5a. J Rheumatol. 1987 Feb;14(1):9-11.

57. Ternowitz T, Bjerring P, Andersen PH, Schroder JM, Kragballe K. Methotrexate inhibits the human 
C5a-induced skin response in patients with psoriasis. J Invest Dermatol. 1987 Aug;89(2):192-6.

58. Lammers AM, van de Kerkhof PC, Mier PD. Reduction of leukotriene B4-induced intraepidermal accumulation of polymorphonuclear leukocytes by methotrexate in psoriasis. $\mathrm{Br} \mathrm{J}$ Dermatol. 1987 May;116(5):667-71.

59. Vrugt B, Wilson S, Bron A, Shute J, Holgate ST, Djukanovic R, et al. Low-dose methotrexate treatment in severe glucocorticoid-dependent asthma: Effect on mucosal inflammation and in vitro sensitivity to glucocorticoids of mitogeninduced T-cell proliferation. Eur Respir J. 2000 Mar;15(3):478-85.

60. Davies H, Olson L, Gibson P. Methotrexate as a steroid sparing agent for asthma in adults. Cochrane Database Syst Rev. 2000;(2)(2):CD000391.

61. Comet R, Domingo C, Larrosa M, Moron A, Rue $\mathrm{M}$, Amengual MJ, et al. Benefits of low weekly doses of methotrexate in steroid-dependent asthmatic patients. A double-blind, randomized, placebo-controlled study. Respir Med. 2006 Mar;100(3):411-9.

62. Kon OM, Kay AB. T cells and chronic asthma. Int Arch Allergy Immunol. 1999 Feb-Apr;118(24):133-5.

63. Corrigan CJ, Brown PH, Barnes NC, Tsai JJ, Frew AJ, Kay AB. Glucocorticoid resistance in chronic asthma. peripheral blood $\mathrm{T}$ lymphocyte activation and comparison of the $\mathrm{T}$ lymphocyte inhibitory effects of glucocorticoids and cyclosporin A. Am Rev Respir Dis. 1991 Nov;144(5):1026-32.

64. Leung DY, Martin RJ, Szefler SJ, Sher ER, Ying S, Kay $\mathrm{AB}$, et al. Dysregulation of interleukin 4, interleukin 5, and interferon gamma gene expression in steroid-resistant asthma. J Exp Med. 1995 Jan 1;181(1):33-40.

65. Leung DY. Steroid-resistant asthma. West J Med. 1995 Oct;163(4):367-8.

66. Alexander AG, Barnes NC, Kay AB. Trial of cyclosporin in corticosteroid-dependent chronic severe asthma. Lancet. 1992 Feb 8;339(8789):3248.

67. Sihra BS, Kon OM, Durham SR, Walker S, Barnes NC, Kay AB. Effect of cyclosporin A on the allergen-induced late asthmatic reaction. Thorax. 1997 May;52(5):447-52.

68. Frew AJ, Plummeridge MJ. Alternative agents in asthma. J Allergy Clin Immunol. $2001 \mathrm{Jul} ; 108(1): 3-$ 10.

69. Evans DJ, Cullinan P, Geddes DM. Cyclosporin as an oral corticosteroid sparing agent in stable asthma. Cochrane Database Syst Rev. 2001;(2)(2):CD002993.

70. Lock SH, Kay AB, Barnes NC. Double-blind, placebo-controlled study of cyclosporin $\mathrm{A}$ as a corticosteroid-sparing agent in corticosteroid- dependent asthma. Am J Respir Crit Care Med. 1996 Feb;153(2):509-14.

71. Nizankowska E, Soja J, Pinis G, Bochenek G, Sladek K, Domagala B, et al. Treatment of steroiddependent bronchial asthma with cyclosporin. Eur Respir J. 1995 Jul;8(7):1091-9.

72. Ledford DK. Treatment of steroid-resistant asthma. Immunology and Allergy Clinics of North America. 1996 NOV; 16(4):777,\&.

73. Evans DJ, Cullinan P, Geddes DM. Gold as an oral corticosteroid sparing agent in stable asthma. Cochrane Database Syst Rev. 2001;(2)(2):CD002985.

74. Muranaka M, Miyamoto T, Shida T, Kabe J, Makino S, Okumura H, et al. Gold salt in the treatment of bronchial asthma--a double-blind study. Ann Allergy. 1978 Feb;40(2):132-7.

75. Nierop G, Gijzel WP, Bel EH, Zwinderman AH, Dijkman JH. Auranofin in the treatment of steroid dependent asthma: A double blind study. Thorax. 1992 May;47(5):349-54.

76. Bernstein IL, Bernstein DI, Dubb JW, Faiferman I, Wallin B. A placebo-controlled multicenter study of auranofin in the treatment of patients with corticosteroid-dependent asthma. auranofin multicenter drug trial. J Allergy Clin Immunol. 1996 Aug;98(2):317-24.

77. Gelfand EW, Landwehr LP, Esterl B, Mazer B. Intravenous immune globulin: An alternative therapy in steroid-dependent allergic diseases. Clin Exp Immunol. 1996 May;104 Suppl 1:61-6.

78. Landwehr LP, Jeppson JD, Katlan MG, Esterl B, McCormick D, Hamilos DL, et al. Benefits of highdose i.v. immunoglobulin in patients with severe steroid-dependent asthma. Chest. 1998 Nov;114(5):1349-56.

79. Mazer BD, Gelfand EW. An open-label study of high-dose intravenous immunoglobulin in severe childhood asthma. J Allergy Clin Immunol. 1991 May;87(5):976-83.

80. Salmun LM, Barlan I, Wolf HM, Eibl M, Twarog FJ, Geha RS, et al. Effect of intravenous immunoglobulin on steroid consumption in patients with severe asthma: A double-blind, placebocontrolled, randomized trial. J Allergy Clin Immunol. 1999 May;103(5 Pt 1):810-5.

81. Leung DY, Burns JC, Newburger JW, Geha RS. Reversal of lymphocyte activation in vivo in the kawasaki syndrome by intravenous gammaglobulin. J Clin Invest. 1987 Feb;79(2):468-72.

82. Amran D, Renz H, Lack G, Bradley K, Gelfand EW. Suppression of cytokine-dependent human Tcell proliferation by intravenous immunoglobulin. Clin Immunol Immunopathol. 1994 Nov;73(2):1806.

83. Spahn JD, Leung DY, Chan MT, Szefler SJ, Gelfand EW. Mechanisms of glucocorticoid 
reduction in asthmatic subjects treated with intravenous immunoglobulin. J Allergy Clin Immunol. 1999 Mar;103(3 Pt 1):421-6.

84. Jakobsson T, Croner S, Kjellman NI, Pettersson A, Vassella C, Bjorksten B. Slight steroid-sparing effect of intravenous immunoglobulin in children and adolescents with moderately severe bronchial asthma. Allergy. 1994 Jul;49(6):413-20.

85. Haque S, Boyce N, Thien FC, O'Hehir RE, Douglass J. Role of intravenous immunoglobulin in severe steroid-dependent asthma. Intern Med $\mathrm{J}$. 2003 Aug;33(8):341-4.

86. Kishiyama JL, Valacer D, Cunningham-Rundles C, Sperber K, Richmond GW, Abramson S, et al. A multicenter, randomized, double-blind, placebocontrolled trial of high-dose intravenous immunoglobulin for oral corticosteroid-dependent asthma. Clin Immunol. 1999 May;91(2):126-33.

87. Burks AW, Sampson HA, Buckley RH. Anaphylactic reactions after gamma globulin administration in patients with hypogammaglobulinemia. detection of $\operatorname{IgE}$ antibodies to IgA. N Engl J Med. 1986 Feb 27;314(9):560-4.

88. Buckley RH, Schiff RI. The use of intravenous immune globulin in immunodeficiency diseases. $\mathrm{N}$ Engl J Med. 1991 Jul 11;325(2):110-7.

89. Manlhiot C, Tyrrell PN, Liang L, Atkinson AR, Lau W, Feldman BM. Safety of intravenous immunoglobulin in the treatment of juvenile dermatomyositis: Adverse reactions are associated with immunoglobulin A content. Pediatrics. 2008 Mar;121(3):e626-30.

90. Stein MR. The new generation of liquid intravenous immunoglobulin formulations in patient care: A comparison of intravenous immunoglobulins. Postgrad Med. 2010 Sep;122(5):176-84.

91. van Furth R, Gassmann AE, Diesselhoff-Den Dulk MM. The effect of azathioprine (imuran) on the cell cycle of promonocytes and the production of monocytes in the bone marrow. J Exp Med. 1975 Mar 1;141(3):531-46.

92. Levy J, Barnett EV, MacDonald NS, Klinenberg JR, Pearson CM. The effect of azathioprine on gammaglobulin synthesis in man. J Clin Invest. 1972 Sep;51(9):2233-8.

93. Liu HN, Wong CK. In vitro immunosuppressive effects of methotrexate and azathioprine on langerhans cells. Arch Dermatol Res. 1997 Jan;289(2):94-7.

94. Gorski A, Korczak-Kowalska G, Nowaczyk M, Paczek L, Gaciong Z. The effect of azathioprine on terminal differentiation of human B lymphocytes. Immunopharmacology. 1983 Dec;6(4):259-66.

95. Elion GB. The george hitchings and gertrude elion lecture. the pharmacology of azathioprine. Ann N Y Acad Sci. 1993 Jun 23;685:400-7.
96. Hodges NG, Brewis RA, Howell JB. An evaluation of azathioprine in severe chronic asthma. Thorax. 1971 Nov;26(6):734-9.

97. HARTUNG EF. History of the use of colchicum and related medicaments in gout; with suggestions for further research. Ann Rheum Dis. 1954 Sep;13(3):190-200.

98. Ilfeld D, Kivity S, Feierman E, Topilsky M, Kuperman O. Effect of in vitro colchicine and oral theophylline on suppressor cell function of asthmatic patients. Clin Exp Immunol. 1985 Aug;61(2):360-7.

99. Caner JE. Colchicine inhibition of chemotaxis. Arthritis Rheum. 1965 Oct;8(5):757-64.

100. Malawista SE, Bodel PT. The dissociation by colchicine of phagocytosis from increased oxygen consumption in human leukocytes. J Clin Invest. 1967 May;46(5):786-96.

101. Hoffstein S, Zurier RB, Weissmann G. Mechanisms of lysosomal enzyme release from human leucocytes. III. quantitative morphologic evidence for an effect of cyclic nucleotides and colchicine on degranulation. Clin Immunol Immunopathol. 1974 Nov;3(2):201-17.

102. Gillespie E, Lichtenstein LM. Histamine release from human leukocytes: Studies with deuterium oxide, colchicine, and cytochalasin B. J Clin Invest. 1972 Nov;51(11):2941-7.

103. Kaliner M. Human lung tissue and anaphylaxis. evidence that cyclic nucleotides modulate the immunologic release of mediators through effects on microtubular assembly. J Clin Invest. 1977 Oct;60(4):951-9.

104. Fish JE, Peters SP, Chambers CV, McGeady SJ, Epstein KR, Boushey HA, et al. An evaluation of colchicine as an alternative to inhaled corticosteriods in moderate asthma. national heart, lung, and blood institute's asthma clinical research network. Am J Respir Crit Care Med. 1997 Oct;156(4 Pt 1):1165-71.

105. Newman KB, Mason UG, Buchmeier A, Schmaling $\mathrm{KB}$, Corsello P, Nelson HS. Failure of colchicine to reduce inhaled triamcinolone dose in patients with asthma. J Allergy Clin Immunol. 1997 Feb;99(2):176-8.

106. Adalioglu G, Turktas I, Saraclar Y, Tuncer A. A clinical study of colchicine in childhood asthma. J Asthma. 1994;31(5):361-6.

107. Schwarz YA, Kivity S, Ilfeld DN, Schlesinger M, Greif J, Topilsky $M$, et al. A clinical and immunologic study of colchicine in asthma. J Allergy Clin Immunol. 1990 Mar;85(3):578-82.

108. Kelly SJ, Uri AJ, Freeland HS, Woods EJ, Schulman ES, Peters SP, et al. Effects of colchicine on IgE-mediated early and late airway reactions. Chest. 1995 Apr;107(4):985-91. 
109. Booth SA, Moody CE, Dahl MV, Herron MJ, Nelson RD. Dapsone suppresses integrin-mediated neutrophil adherence function. J Invest Dermatol. 1992 Feb;98(2):135-40.

110. Thuong-Nguyen V, Kadunce DP, Hendrix JD, Gammon WR, Zone JJ. Inhibition of neutrophil adherence to antibody by dapsone: A possible therapeutic mechanism of dapsone in the treatment of IgA dermatoses. J Invest Dermatol. 1993 Apr;100(4):349-55.

111. Berlow BA, Liebhaber MI, Dyer Z, Spiegel TM. The effect of dapsone in steroid-dependent asthma. J Allergy Clin Immunol. 1991 Mar;87(3):710-5.

112. Fox RI. Mechanism of action of hydroxychloroquine as an antirheumatic drug. Semin Arthritis Rheum. 1993 Oct;23(2 Suppl 1):8291.

113. Fox RI, Kang HI. Mechanism of action of antimalarial drugs: Inhibition of antigen processing and presentation. Lupus. 1993 Feb;2 Suppl 1:S9-12.

114. Charous BL, Halpern EF, Steven GC. Hydroxychloroquine improves airflow and lowers circulating IgE levels in subjects with moderate symptomatic asthma. J Allergy Clin Immunol. 1998 Aug;102(2):198-203.

115. Goldstein JA. Hydroxychloroquine for asthma. Am Rev Respir Dis. 1983 Dec;128(6):1100-1.

116. Roberts JA, Gunneberg A, Elliott JA, Thomson NC. Hydroxychloroquine in steroid dependent asthma. Pulm Pharmacol. 1988;1(1):59-61.

117. Lichtenstein LM, Bochner BS. The role of basophils in asthma. Ann N Y Acad Sci. 1991;629:48-61.

118. Boyce JA, Broide D, Matsumoto K, Bochner BS. Advances in mechanisms of asthma, allergy, and immunology in 2008. J Allergy Clin Immunol. 2009 Mar;123(3):569-74.

119. Oettgen HC, Geha RS. IgE regulation and roles in asthma pathogenesis. J Allergy Clin Immunol. 2001 Mar;107(3):429-40.

120. Horn BR, Robin ED, Theodore J, Van Kessel A. Total eosinophil counts in the management of bronchial asthma. N Engl J Med. 1975 May 29;292(22):1152-5.

121. Bousquet J, Chanez P, Lacoste JY, Barneon G, Ghavanian N, Enander I, et al. Eosinophilic inflammation in asthma. N Engl J Med. 1990 Oct 11;323(15):1033-9.

122. Frew AJ, Kay AB. Eosinophils and T-lymphocytes in late-phase allergic reactions. J Allergy Clin Immunol. 1990 Mar;85(3):533-9.

123. Morjaria JB, Gnanakumaran G, Babu KS. Anti-IgE in allergic asthma and rhinitis: An update. Expert Opin Biol Ther. 2007 Nov;7(11):1739-47.

124. Broide DH. Molecular and cellular mechanisms of allergic disease. J Allergy Clin Immunol. 2001 Aug;108(2 Suppl):S65-71.
125. Fahy JV, Fleming HE, Wong HH, Liu JT, Su JQ, Reimann $J$, et al. The effect of an anti-IgE monoclonal antibody on the early- and late-phase responses to allergen inhalation in asthmatic subjects. Am J Respir Crit Care Med. 1997 Jun;155(6):1828-34.

126. Boulet LP, Chapman KR, Cote J, Kalra S, Bhagat $\mathrm{R}$, Swystun VA, et al. Inhibitory effects of an antiIgE antibody E25 on allergen-induced early asthmatic response. Am J Respir Crit Care Med. 1997 Jun;155(6):1835-40.

127. Walker S, Monteil M, Phelan K, Lasserson TJ, Walters EH. Anti-IgE for chronic asthma in adults and children. Cochrane Database Syst Rev. 2006 Apr 19;(2)(2):CD003559.

128. Ohta K, Miyamoto T, Amagasaki T, Yamamoto M, 1304 Study Group. Efficacy and safety of omalizumab in an asian population with moderateto-severe persistent asthma. Respirology. 2009 Nov;14(8):1156-65.

129. Lanier B, Bridges T, Kulus M, Taylor AF, Berhane I, Vidaurre CF. Omalizumab for the treatment of exacerbations in children with inadequately controlled allergic (IgE-mediated) asthma. J Allergy Clin Immunol. 2009 Dec;124(6):1210-6.

130. Massanari M, Milgrom H, Pollard S, Maykut RJ, Kianifard F, Fowler-Taylor A, et al. Adding omalizumab to the therapy of adolescents with persistent uncontrolled moderate--severe allergic asthma. Clin Pediatr (Phila). 2009 Oct;48(8):85965.

131. Bradding P, Roberts JA, Britten KM, Montefort S, Djukanovic R, Mueller R, et al. Interleukin-4, -5, and -6 and tumor necrosis factor-alpha in normal and asthmatic airways: Evidence for the human mast cell as a source of these cytokines. Am J Respir Cell Mol Biol. 1994 May;10(5):471-80.

132. Broide DH, Lotz M, Cuomo AJ, Coburn DA, Federman EC, Wasserman SI. Cytokines in symptomatic asthma airways. J Allergy Clin Immunol. 1992 May;89(5):958-67.

133. Ying S, Robinson DS, Varney V, Meng Q, Tsicopoulos A, Moqbel R, et al. TNF alpha mRNA expression in allergic inflammation. Clin Exp Allergy. 1991 Nov;21(6):745-50.

134. Howarth PH, Babu KS, Arshad HS, Lau L, Buckley $\mathrm{M}$, McConnell $\mathrm{W}$, et al. Tumour necrosis factor (TNFalpha) as a novel therapeutic target in symptomatic corticosteroid dependent asthma. Thorax. 2005 Dec;60(12):1012-8.

135. Berry MA, Hargadon B, Shelley M, Parker D, Shaw DE, Green RH, et al. Evidence of a role of tumor necrosis factor alpha in refractory asthma. N Engl J Med. 2006 Feb 16;354(7):697-708.

136. Thomas PS, Yates DH, Barnes PJ. Tumor necrosis factor-alpha increases airway responsiveness and 
sputum neutrophilia in normal human subjects. Am J Respir Crit Care Med. 1995 Jul;152(1):76-80.

137. Thomas PS, Heywood G. Effects of inhaled tumour necrosis factor alpha in subjects with mild asthma. Thorax. 2002 Sep;57(9):774-8.

138. Scheurich P, Thoma B, Ucer U, Pfizenmaier K. Immunoregulatory activity of recombinant human tumor necrosis factor (TNF)-alpha: Induction of TNF receptors on human $T$ cells and TNF-alphamediated enhancement of $\mathrm{T}$ cell responses. J Immunol. 1987 Mar 15;138(6):1786-90.

139. Slungaard A, Vercellotti GM, Walker G, Nelson RD, Jacob HS. Tumor necrosis factor alpha/cachectin stimulates eosinophil oxidant production and toxicity towards human endothelium. J Exp Med. 1990 Jun 1;171(6):202541.

140. Huber M, Beutler B, Keppler D. Tumor necrosis factor alpha stimulates leukotriene production in vivo. Eur J Immunol. 1988 Dec;18(12):2085-8.

141. Lukacs NW, Strieter RM, Chensue SW, Widmer M, Kunkel SL. TNF-alpha mediates recruitment of neutrophils and eosinophils during airway inflammation. J Immunol. 1995 May 15;154(10):5411-7.

142. Erin EM, Leaker BR, Nicholson GC, Tan AJ, Green $\mathrm{LM}$, Neighbour $\mathrm{H}$, et al. The effects of a monoclonal antibody directed against tumor necrosis factor-alpha in asthma. Am J Respir Crit Care Med. 2006 Oct 1;174(7):753-62.

143. Rouhani FN, Meitin CA, Kaler M, MiskinisHilligoss D, Stylianou M, Levine SJ. Effect of tumor necrosis factor antagonism on allergenmediated asthmatic airway inflammation. Respir Med. 2005 Sep;99(9):1175-82.

144. Morjaria JB, Chauhan AJ, Babu KS, Polosa R, Davies DE, Holgate ST. The role of a soluble TNFalpha receptor fusion protein (etanercept) in corticosteroid refractory asthma: A double blind, randomised, placebo controlled trial. Thorax. 2008 Jul;63(7):584-91.

145. Wenzel SE, Barnes PJ, Bleecker ER, Bousquet J, Busse W, Dahlen SE, et al. A randomized, doubleblind, placebo-controlled study of tumor necrosis factor-alpha blockade in severe persistent asthma. Am J Respir Crit Care Med. 2009 Apr 1;179(7):549-58.

146. Rennard SI, Fogarty C, Kelsen S, Long W, Ramsdell J, Allison J, et al. The safety and efficacy of infliximab in moderate to severe chronic obstructive pulmonary disease. Am J Respir Crit Care Med. 2007 May 1;175(9):926-34.

147. Bongartz T, Sutton AJ, Sweeting MJ, Buchan I, Matteson EL, Montori V. Anti-TNF antibody therapy in rheumatoid arthritis and the risk of serious infections and malignancies: Systematic review and meta-analysis of rare harmful effects in randomized controlled trials. JAMA. 2006 May 17;295(19):2275-85.

148. Brown SL, Greene MH, Gershon SK, Edwards ET, Braun MM. Tumor necrosis factor antagonist therapy and lymphoma development: Twenty-six cases reported to the food and drug administration. Arthritis Rheum. 2002 Dec;46(12):3151-8.

149. Diak P, Siegel J, La Grenade L, Choi L, Lemery S, McMahon A. Tumor necrosis factor alpha blockers and malignancy in children: Forty-eight cases reported to the food and drug administration. Arthritis Rheum. 2010 Aug;62(8):2517-24.

150. Nader HB, Lopes CC, Rocha HA, Santos EA, Dietrich CP. Heparins and heparinoids: Occurrence, structure and mechanism of antithrombotic and hemorrhagic activities. Curr Pharm Des. 2004;10(9):951-66.

151. Kobayashi S, Somlyo AV, Somlyo AP. Heparin inhibits the inositol 1,4,5-trisphosphate-dependent, but not the independent, calcium release induced by guanine nucleotide in vascular smooth muscle. Biochem Biophys Res Commun. 1988 Jun 16;153(2):625-31.

152. Ghosh TK, Eis PS, Mullaney JM, Ebert CL, Gill DL. Competitive, reversible, and potent antagonism of inositol 1,4,5-trisphosphate-activated calcium release by heparin. J Biol Chem. 1988 Aug 15;263(23):11075-9.

153. Tones MA, Bootman MD, Higgins BF, Lane DA, Pay GF, Lindahl U. The effect of heparin on the inositol 1,4,5-trisphosphate receptor in rat liver microsomes. dependence on sulphate content and chain length. FEBS Lett. 1989 Jul 31;252(1-2):1058.

154. Worley PF, Baraban JM, Supattapone S, Wilson VS, Snyder SH. Characterization of inositol trisphosphate receptor binding in brain. regulation by $\mathrm{pH}$ and calcium. J Biol Chem. 1987 Sep 5;262(25):12132-6.

155. Ahmed T, Abraham WM, D'Brot J. Effects of inhaled heparin on immunologic and nonimmunologic bronchoconstrictor responses in sheep. Am Rev Respir Dis. 1992 Mar;145(3):56670.

156. Ahmed T, Syriste T, Lucio J, Abraham W, Robinson M, D'Brot J. Inhibition of antigeninduced airway and cutaneous responses by heparin: A pharmacodynamic study. J Appl Physiol. 1993 Apr;74(4):1492-8.

157. Abraham WM, Abraham MK, Ahmed T. Protective effect of heparin on immunologically induced tracheal smooth muscle contraction in vitro. Int Arch Allergy Immunol. 1996 May;110(1):79-84.

158. Lucio J, D'Brot J, Guo CB, Abraham WM, Lichtenstein LM, Kagey-Sobotka A, et al. Immunologic mast cell-mediated responses and 
histamine release are attenuated by heparin. J Appl Physiol. 1992 Sep;73(3):1093-101.

159. Bowler SD, Smith SM, Lavercombe PS. Heparin inhibits the immediate response to antigen in the skin and lungs of allergic subjects. Am Rev Respir Dis. 1993 Jan;147(1):160-3.

160. BOYLE JP, SMART RH, SHIREY JK. Heparin in the treatment of chronic obstructive bronchopulmonary disease. Am J Cardiol. 1964 Jul; $14: 25-8$.

161. Fine NL, Shim C, Williams MH,Jr. Objective evaluation of heparin in the treatment of asthma. Am Rev Respir Dis. 1968 Nov;98(5):886-7.

162. Bardana EJ,Jr, Edwards MJ, Pirofsky B. Heparin as treatment for bronchospasm of asthma. Ann Allergy. 1969 Mar;27(3):108-13.

163. Ahmed T, Garrigo J, Danta I. Preventing bronchoconstriction in exercise-induced asthma with inhaled heparin. N Engl J Med. 1993 Jul 8;329(2):90-5.

164. Garrigo J, Danta I, Ahmed T. Time course of the protective effect of inhaled heparin on exerciseinduced asthma. Am J Respir Crit Care Med. 1996 May;153(5):1702-7.

165. Ahmed T, Gonzalez BJ, Danta I. Prevention of exercise-induced bronchoconstriction by inhaled low-molecular-weight heparin. Am J Respir Crit Care Med. 1999 Aug;160(2):576-81.

166. Ceyhan B, Celikel T. Effect of inhaled heparin on methacholine-induced bronchial hyperreactivity. Chest. 1995 Apr;107(4):1009-12.

167. Pavord I, Mudassar T, Bennett J, Wilding P, Knox A. The effect of inhaled heparin on bronchial reactivity to sodium metabisulphite and methacholine in patients with asthma. Eur Respir J. 1996 Feb;9(2):217-9.

168. Kalpaklioglu AF, Demirel YS, Saryal S, Misirligil Z. Effect of pretreatment with heparin on pulmonary and cutaneous response. J Asthma. 1997;34(4):337-43.

169. Bendstrup KE, Jensen JI. Inhaled heparin is effective in exacerbations of asthma. Respir Med. $2000 \mathrm{Feb} ; 94(2): 174-5$.

170. Weitz JI, Young E, Johnston M, Stafford AR, Fredenburgh JC, Hirsh J. Vasoflux, a new anticoagulant with a novel mechanism of action. Circulation. 1999 Feb 9;99(5):682-9.

171. Brater DC. Clinical pharmacology of loop diuretics. Drugs. 1991;41 Suppl 3:14-22.

172. Elwood W, Lotvall JO, Barnes PJ, Chung KF. Loop diuretics inhibit cholinergic and noncholinergic nerves in guinea pig airways. Am Rev Respir Dis. 1991 Jun;143(6):1340-4.

173. Knox AJ, Ajao P. Effect of frusemide on airway smooth muscle contractility in vitro. Thorax. 1990 Nov;45(11):856-9.

174. Perkins RS, Dent G, Chung KF, Barnes PJ. The effect of anion transport inhibitors and extracellular cl- concentration on eosinophil respiratory burst activity. Biochem Pharmacol. 1992 Jun 9;43(11):2480-3.

175. Bianco S, Vaghi A, Robuschi M, Refini RM, Pieroni MG, Sestini P. Steroid-sparing effect of inhaled lysine acetylsalicylate and furosemide in high-dose beclomethasone-dependent asthma. J Allergy Clin Immunol. 1995 May;95(5 Pt 1):93743.

176. Bianco S, Pieroni MG, Refini RM, Robuschi M, Vaghi A, Sestini P. Inhaled loop diuretics as potential new anti-asthmatic drugs. Eur Respir J. 1993 Jan;6(1):130-4.

177. Karpel JP, Dworkin F, Hager D, Feliciano S, Shapiro D, Posner L, et al. Inhaled furosemide is not effective in acute asthma. Chest. 1994 Nov;106(5):1396-400.

178. Ono Y, Kondo T, Tanigaki T, Ohta Y. Furosemide given by inhalation ameliorates acute exacerbation of asthma. J Asthma. 1997;34(4):283-9.

179. Pendino JC, Nannini LJ, Chapman KR, Slutsky A, Molfino NA. Effect of inhaled furosemide in acute asthma. J Asthma. 1998;35(1):89-93.

180. Tanigaki T, Kondo T, Hayashi Y, Katoh H, Kamio $\mathrm{K}$, Urano $\mathrm{T}$, et al. Rapid response to inhaled frusemide in severe acute asthma with hypercapnia. Respiration. 1997;64(1):108-10.

181. Heaney LG, Conway E, Kelly C, Johnston BT, English C, Stevenson M, et al. Predictors of therapy resistant asthma: Outcome of a systematic evaluation protocol. Thorax. 2003 Jul;58(7):561-6. 